\title{
Organizational Buying Behavior of Selected Leather Footwear Exporting Companies in Addis Ababa, Ethiopia
}

\author{
Rahwa Aregawi*
}

\begin{abstract}
The purpose of this study is to assess the buying behavior of the Ethiopian leather footwear exporting companies in terms of supplier selection criteria, buying center, and factors affecting the purchasing process. In order to achieve the objective, a multiple case study approach is used in three case companies. The companies are Anbessa Shoe Share Company, Tikur Abbay Shoe Share Company and Peacock Shoe Company. The source of evidence is a personal interview conducted with the three case company managers. Furthermore, the data was evaluated using within-case analysis for easy data reduction, data display and drawing and verifying conclusions followed by a cross-case analysis. And the results indicated that quality and delivery are the most important criteria by case companies. Production facilities and capacity, financial position, procedural compliance and communication system are considerably important. The buying centers communication network and player in straight re-buy is the same as in modified re-buy. Likely, the roles in the buying center in both straight re-buy and modified re-buy is similar. Finally, the environmental, organizational, buying center and individual factors are influencing the buying process of the case companies. Thus, managers should clearly realize their buying center activities and internal and external factors in order to have smooth relationships with the finished leather suppliers and improve their footwear export performances.
\end{abstract}

Keywords: organizational buying behavior, supplier selection criteria, buying center

DOI: http://dx.doi.org/10.4314/ejbe.v4i2.4

*Leather Industry Development Institute, Addis Ababa, Ethiopia, E-mail:kecho.cheru@gmail.com 
Organizational Buying Behavior of Companies in Ethiopia

\section{Introduction}

\subsection{Background of the Study Pertinent}

Ethiopia possesses one of the largest populations of livestock in Africa, which provides the major raw material for the production of leather products including footwear (CSA, 2012/13a). And this huge potential resource is the major input for the leather sector to be further flourished. According to LIDI (2013) the leather sector is envisaged to generate export income amounting 500 million USD at the end of the plan year (2014/15). Furthermore, the leather industry especially the footwear products are one of the major sources of foreign currency through export. These footwear companies use finished leather as an input for the day to day production process and they frequently practice the notion of organizational buying behavior. Therefore, this paper intended to clearly describe the Ethiopian leather footwear exporting companies' buyer behavior when purchasing finished leather.

The researcher has given greater emphasis to the leather sector because it has a strategic attention and support by the government of Ethiopia. Furthermore, the leather industry especially the footwear products are one of the major sources of foreign currency through export. And lastly from the prior investigation conducted, the researcher understood the knowledge gap of organizational buying behavior by the footwear companies as well as the leather industry.

\subsection{Statement of the Problem}

According to Mekonnen and Gezahegn (2008); Mulualem (2002) finished leather is not fully utilized by the leather industries. And the main reasons are: poor relationship among buyers and suppliers', poor livestock management, and poor quality raw material. As a result, the supply chain of finished leather in the industry is facing huge challenges. To this effect the overall export performance of the companies is affected (Ibid). Moreover, series of studies that have been conducted on the Ethiopian leather footwear industry, confirmed that such problems are affecting the overall purchasing process of the companies. For instance, a study conducted by Japan Embassy revealed that proper utilization of finished leather for footwear production is low. This is 
because the footwear manufacturing companies are facing a shortage of quality finished leather, long procurement lead time, and inefficient utilization of resources i.e. material, machine, and labor (Tomas, 2011).

In addition, the researcher realized from the preliminary investigation that the finished leather challenges are related to supplier loyalty, quality, quantity of the leather and excessive delaying of the inputs. However, the companies did not clearly understand and give attention to their buying activities though they are facing many challenges. On the other hand, several authors and researchers explained the importance of understanding the organization's buying behavior by company managers. According to Buvik, (2001) organizational buying behavior is knowledge about how purchasing departments and buying centers organize purchasing process making conditions that influence their purchase. Therefore, the main purpose of this study is describing the buying behavior of Ethiopian leather footwear exporting companies. Likewise, the research tried to identify the understanding gap that occurres in the leather footwear companies of buying behavior and clearly describes the components included in the process.

\subsection{Research Questions}

RQ.1: How can the buying behavior of Ethiopian leather footwear companies be described in terms of the buying center?

RQ.2: What criteria do footwear manufacturing companies use when they select suppliers for purchasing the finished leather?

RQ.3: How can the factors affecting Ethiopian Leather Footwear Companies' buying process be described?

\subsection{Objectives of the Study 1.4.1. General Objective}

The general objective of the study is to assess the buying behavior of selected Ethiopian leather footwear exporting companies in relation to nature of buying center, supplier selection criteria, and factors affecting their buying practices of finished leather from different suppliers.

EJBE Vol. 4 No. 2/2014

Page 285 
Organizational Buying Behavior of Companies in Ethiopia

\subsubsection{Specific Objectives}

The specific objective of the study is to:

Examine the buying center activities in the Ethiopian leather footwear manufacturing companies of purchasing finished leather.

Describe the criteria leather footwear manufacturing companies use when they select suppliers in purchasing finished leather.

$>$ Identify factors affecting the purchasing process of Ethiopian leather footwear manufacturing companies.

1.5. Definition of Key Terms: Conceptual and Operational definitions used

Organizational Buying behavior: is a complex process over time that involves interaction between several persons, both within and outside an organization (Webster and Wind, 1972).

> Buying center: refers to all those members of an organization who become involved in the buying process for a particular product or service (Robinson et al., 1967).

$>$ Raw material: include all raw and auxiliary materials, parts and containers which are consumed during the reference year (CSA, 2012/13b).

\subsection{Significance of the Study}

This study mainly helps the case companies, particularly the purchasing managers by describing their buying activities. As the government of Ethiopia gave huge focus to the leather industry, the result of this study can provide important information to the concerned bodies (i.e. Industry Minister, Trade Minister, and Leather Industry Development Institute). Likewise, researchers and students who wish to conduct studies related to this research area can get an input for their studies.

\subsection{Scope of the Study}

Considering the resource and time constraint, the study is mainly limited to three Ethiopian leather footwear exporting companies which are located in 
Addis Ababa, Ethiopia. Moreover, it focuses on the companies buying behavior with respect to the purchasing of finished leather. Although there are other types of input materials under the companies buying practice, the study only examines the finished leather material. Basing the research objective, a descriptive research design was used in order to gain deep understanding on the issue. Moreover, an interview was the major instrument in collecting the data.

\section{Theoretical Framework}

\section{Organizational buying behavior}

Organizational buying, according to Webster and Wind (1972) is 'the process making process by which formal organizations establish the need for purchased products and services and identify, evaluate and choose among alternative brands and suppliers'.Much of the buying and selling in advanced economies is between organizations, that is, industrial rather than consumer market exchange thus, it is important to understand organizational buying behavior (Anderson et al. 1987).There are a number of stages, or phases, associated with product and service procurement, each one often requiring a key process to be made. Additionally, it usually involves many people in the process with complex inter-actions among people and among individual and organizational goals. Thus, requires information from many sources, and encompasses many inter-organizational relationships (ibid).

Furthermore, buyers face a complex set of issues and their behaviors are confounded by many situational factors (Bunn, 1993). It is important to understand what influences that are being involved and how they are likely to impact the buying process to be able to understand why buyers make particular choices (Kotler et al. 1996).

According to Webster and Wind (1972), Organizational buying behavior is a complex process over time that involves interaction between several persons, both within and outside an organization.Furthermore, Wind and Thomas (1980) as cited by Goncalved and Vaquer (2006) characterized the industrial 
Organizational Buying Behavior of Companies in Ethiopia

buying behavior (IBB) in to three major aspects: The Buying Process, The Buying Center and Factors Affecting the Organizational Buying center and Process.

\subsection{The buying process}

The Canadian, American and Israeli marketing researchers, Robinson, Faris and Windin (1967) introduced the buy grid framework as a generic conceptual model for buying processes of organizations.According to Hass (1995) of all the models of organizational buying behavior that have been developed, the buy grid has been the most enduring.The framework for analysis of industrial buying situations combines eight buy phases.

\section{Selection criteria}

Selection criteria, the sixth phase of buying process, was suggested by Robinson et al. (1967).The major objective of the buy phase number six in the buy grid framework is to determine the optimal supplier who offers the best all-round package of a product. The vendor selection has long been recognized as important and according to Cheraghi et al. (2004) supplier selection problem is of vital importance for operation of every firm because the solution of this problem can directly and substantially affect costs and quality. An interesting work, which is a reference for the majority of papers dealing with suppliers or vendor selection problem, was presented by Dickson in 1966. Dickson's 23 are ranked with respect to their importance observed in the beginning of the sixties.Out of the 23 criteria's of Dickson, the top 10 ranked criteria are considered in this study and are presented below in the following table.

EJBE Vol. 4 No. 2/2014 
Organizational Buying Behavior of Companies in Ethiopia

\section{Table 2.1: Dickson's vender selection criteria}

\begin{tabular}{|l|l|l|l|}
\hline Rank & Factor & Mean Rating & Evaluation \\
\cline { 1 - 3 } & Quality & 3.508 & \\
\cline { 1 - 3 } Extreme \\
importance
\end{tabular}

Source: adapted from Dickson, 1966

\section{Buy classes}

The buying situation has long been recognized as vital in industrial buying behavior (Robinson et al. 1967). They divided the buying process into novel, straight re-buy, and modified re-buy.

New task: The first-time purchase seeks a wide variety of information to explore alternative purchasing solutions to its organizational problem.

> Straight re-buy: is the most common in industrial purchasing (Robinson et al, 1967). The buyer routinely reorders a product with no modifications. In a straight re-buy, some variations may occur from time to time in the quantity, physical or chemical properties, delivery time, method of shipment or the price, so long as these changes do not entail a re-evaluation of the purchasing alternatives nor cause any changes in the procurement process and patterns.

Modified re-buy: The buyer wants to replace a product the organization uses. The process making may involve plans to modify the product 
Organizational Buying Behavior of Companies in Ethiopia

specifications, prices, terms or suppliers when managers of the company believe that such a change will enhance quality or reduce cost.

\subsection{The buying center}

The concept of the buying center refers to all those members of an organization who become involved in the buying process for a particular product or service (Robinson et al. 1967). Johnston and Bonoma (1981) justify that it was Robinson et al. who first used the concept of buying center in 1967.

\subsubsection{Dimensions of buying center}

From their theoretical perspective, Johnston and Bonoma (1981) suggested the five (5) interactive dimensions of buying center. The dimensions are; vertical involvement which refers to the number of levels of the organization's authority hierarchy exerting influence and communicating within the buying center. Lateral involvement the number of separate departments, divisions, or firm functional areas involved in the purchase process. Extensivity refers to the total number of individuals involved in the buying communication network. Connectedness of those involved in the buying communication network and lastly Centrality refers to the degree of the buying manager influence on the process.

\subsubsection{Roles in the buying center}

Bonama (1982) has concluded that the buying center includes all members of the organization who play any of six roles in the buying process. Initiator refers to the individuals within the organization who first recognize the need for a service for a service or product. Gatekeepers are individuals, who may have the title of buyer or purchasing manager, usually act as problem or product experts. Influencers are those who" have a say" in whether a purchase is made and what is bought. Deciders are those who say yes or no to the contemplated purchase. Purchasers/ Buyers are those concerned respectively, with obtaining the product or service. Users are those concerned respectively,

EJBE Vol. 4 No. 2/2014

Page 290 
with consuming the product or service.

\subsection{Factors that affect the buying process}

There are a number of forces that shape the way organizations purchase products or service. Organizational buying behavior takes place in an environment which can change quickly and dynamically (Fill and Mckee, 2011). Thus, the organization's buying process and activity can be influenced easily by the forces. Webster and Wind developed four classes of variables influencing the buying center and the buying process in 1972. These four factors are:

Environmental Factors: includes economic, technological, political, legal, and cultural factors.

Organizational Factors: According to Harold J. Leavitt's 1964 scheme, organizations are multivariate systems composed of four sets of interacting variables: tasks, structure, technology and people" (quoted from Webster and Wind 1972).

Buying Center Factors: Since people operate as part of the total organization, the behavior of members of the buying center reflects the influence of others as well as the effect of the buying task, the organizational structure, and technology.

Individual Factors: Each participant in the buying process brings in personal motives, perceptions and preferences according to Kotler et al. (1996).The individual is at the center of the buying process, operating within the buying center that is in turn bounded by the formal organization which is likewise embedded in the influences of the broader environment.

\subsubsection{Case studies in organizational buying behavior}

As empirical component, this research considered two (2) studies done by krig and Stenstrom (2001) on buying behavior in Swedish Heavy Truck Corporation and Chisakulo (2002) on buying behavior of Lubricants in Zambian Industry, KITWE based companies. Moreover, Krig and Stenstrom used variables (i.e. supplier selection criteria, the dimensions and roles in the 
Organizational Buying Behavior of Companies in Ethiopia

buying center). Chisakulo also used variables like (buy class, buying center, supplier selection criteria and factors affecting buying process).

Figure 2.1: Conceptual Framework of the Study

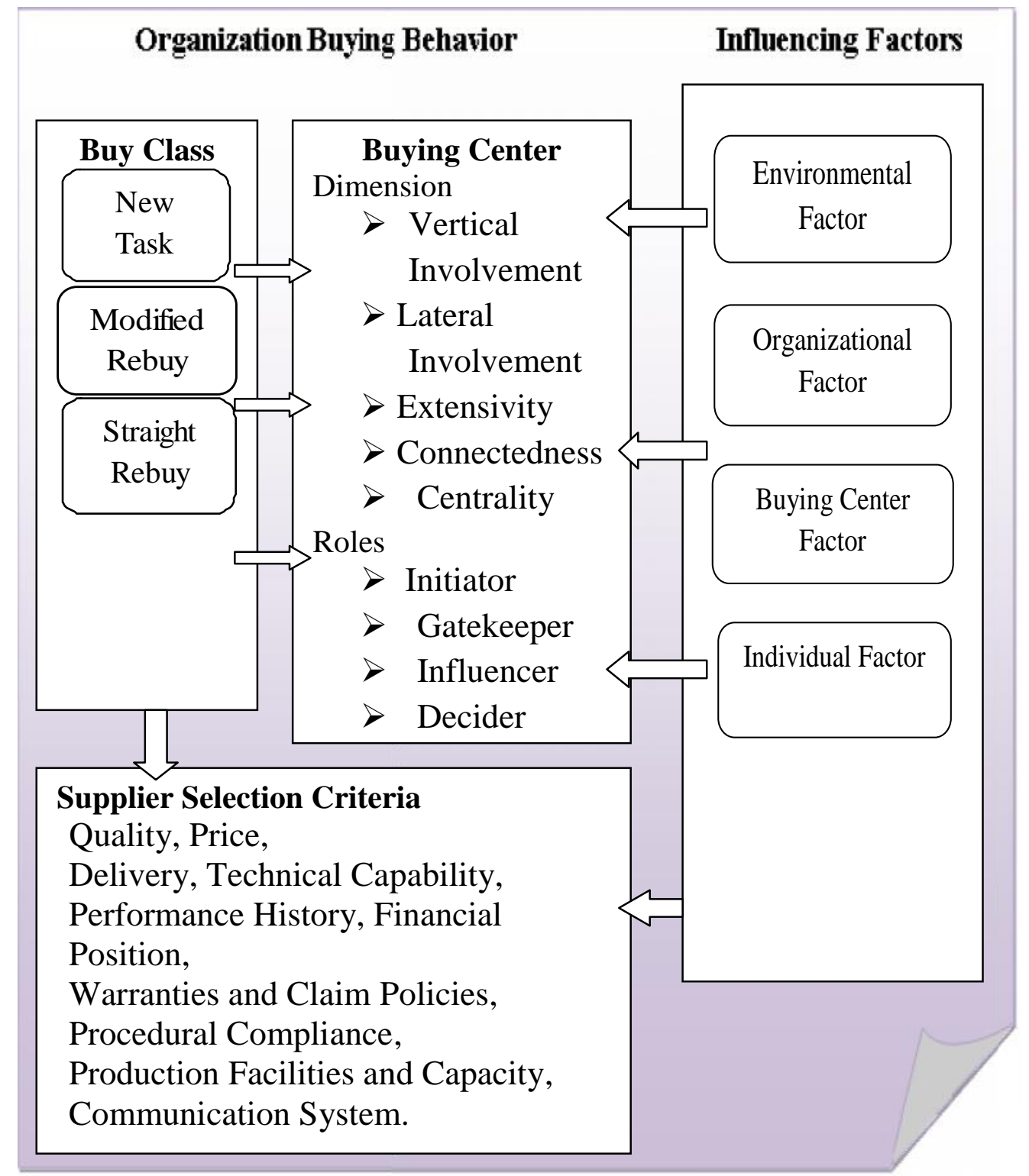

Source: Compilation from Multiple Sources

EJBE Vol. 4 No. 2/2014

Page 292 


\section{Research Methodology}

\subsection{Research Design}

To clearly assess the buyer behavior of footwear export companies in purchasing finished leather, a descriptive research design was used supported by an interview. The design was chosen because it can provide detail information by describing the area of study in theory as well as in reality.

\subsection{Research Approach}

As the researcher aims to identify and describe the research questions in the form of words and explanations instead of collection of results in numerical data, a qualitative approach was chosen.

\subsection{Research Strategy}

Bearing in mind the research problem and research questions, a case study was carried out. A case study is selected because there is no possibility to control the behavioral events related to the research purpose and the study is focused on contemporary events. Furthermore, according to Yin (2003) a case study can involve a single and multiple-case study. Thus, considering Yin's explanation, a multiple or multi-case study were used.

\subsection{Population and Sampling}

The target population of the study includes 10 leather footwear exporting companies, which are identified in LIDI (2013) annual shoe export performance report, 2012/13. The companies are: (Anbessa, Bostex, Jamaica, Kangaroo, New Wing, Peacock, Ramsay, Ras Dashen, TikurAbbay, and Walia Shoe Companies).

Given the time and research approach, the study focused on three (3) exporting companies (i.e. Anbessa Shoe Share Company, Peacock Shoe Company and TikurAbbay Shoe Share Company). In choosing the samples, the under mentioned parameters are considered. Moreover, the cases were selected using 
Organizational Buying Behavior of Companies in Ethiopia

replication logic, in accordance with Yin's (2003) discussion. The researcher anticipated that a multi-case study will produce somewhat similar results.

\section{Table 3.1: Dickson's vender selection criteria}

\begin{tabular}{|l|l|c|c|c|c|c|}
\hline NO. & $\begin{array}{l}\text { Company } \\
\text { Name }\end{array}$ & $\begin{array}{c}\text { Experi } \\
\text { ence }\end{array}$ & $\begin{array}{c}\text { Manp } \\
\text { ower }\end{array}$ & $\begin{array}{c}\text { Actual } \\
\text { Production } \\
\text { (pairs/day) }\end{array}$ & $\begin{array}{c}\text { Export } \\
\text { Market } \\
(\%)\end{array}$ & $\begin{array}{c}\text { Export } \\
\text { Performance } \\
\text { Share in } \\
\text { Revenue (\%) }\end{array}$ \\
\hline 1 & $\begin{array}{l}\text { Anbessa } \\
\text { Shoe } \\
\text { Share } \\
\text { Company }\end{array}$ & 75 & 927 & 2000 & 74 & 12.7 \\
\hline 2 & $\begin{array}{l}\text { Tikure } \\
\text { Abbay } \\
\text { Shoe } \\
\text { Share } \\
\text { company }\end{array}$ & 66 & 572 & 3500 & 80 & 16.8 \\
\hline 3 & $\begin{array}{l}\text { Peacock } \\
\text { Shoe } \\
\text { Company }\end{array}$ & 25 & 320 & 1500 & 90 & 25.0 \\
\hline
\end{tabular}

And the assumption is based on the similarity of the companies in terms of input, process and output and operating in one leather industry. Also basing company's performance and activity a sample is selected purposively.

\subsection{Data Collection and Instrument}

Both primary and secondary sources of data were used. The instruments that are used to collect the primary data are a face- to-face interview with three purchasing managers. The interview instrument was semi-structured interview guided by the emerged frame of reference of the study. The interview response was also supported by research's direct observation. As secondary source, documentations were used collected from accepted sources. Thus, publications

EJBE Vol. 4 No. 2/2014 
from articles, journals, and books were used. Moreover, websites and nonpublished materials i.e. annual company reports were also used.

\subsection{Data Collection Procedures}

The interview was conducted by the researcher in the three selected leather footwear manufacturing companies sequentially. It was held in the office which the interviewees would be available. Moreover, the interview was conducted during lunch time which was a good opportunity to discuss clearly without interrupting the work. The interview questionnaires were checked by three leather experts from Leather Industry Development Institute and pretested by selected one (1) footwear exporting company for any inconsistency, ambiguity and errors. The pilot company is chosen based on years of experience and the confidentiality or trust the researcher has of providing convenient and related information. Finally, the researcher observed the buying activity of the companies in process while the respondents perform their regular work.

\subsection{Method of Data Analysis}

After the data has been screened for completeness, a qualitative method of analysis was used. And this paper followed Holme and Solvang's (1991) recommendation as cited by Saunders et al. (2009), beginning with a withincase analysis followed by a cross-case analysis. Both within-case and crosscase analyses are used to reduce the data, display the data and to draw and verify the conclusion.

\subsection{Ethical Considerations}

As the participants are representing the footwear companies as well as the overall leather footwear industry, consideration of consent, confidentiality and data protection ought to be decisive. In order to secure consent of the selected participants, the researcher first communicated the objective of the research so that they have a clear picture of the study. Moreover the interview questions were forwarded to respondents before conducting the interview, for clear 
understanding and avoiding errors in their answers. Furthermore, the researcher gave an explanation regarding the confidentiality of their identity and the information that they did not wish to disclose. Thus, only relevant information that helped in answering the research questions was included.

\section{Result and Discussion}

\subsection{Validity and Reliability of the Study}

Construct Validity: The study tried to increase and construct validity by using multiple sources of evidence (i.e. Documentation, interviewing and observation) in accordance with the principle of triangulation. Besides, chain of evidence was established throughout the entire report and allowing feedback from three (3) leather experts from leather industry development institute.

External Validity: The researcher inferred a specific set of results to some broader theory, not to other case studies. Furthermore, replication logic has been considered as proposed by Yin (1994) in multi-case study.

Internal Validity: Was neglected as the design of the study was descriptive. Yin (1994) defines internal validity as the establishment of a causal relationship whereby certain conditions are shown to lead to other conditions, as distinguished from fake relationships.

Reliability: The stability of the used instruments was measured by describing the procedures and steps being followed and also records were kept properly (i.e. interview dialogs were tape recorded). Besides, the researcher tried to make as many steps as operational as possible.

\subsection{Within - Case Analysis}

The within-case analysis helped in organizing and structuring the data of the companies independently. Besides, this analysis helps only to get to the next analysis method which is the cross-case analysis of the data.

However, to roughly present the process of the analysis; supplier selection criteria, dimensions and roles in buying center and factors influencing the 
buying process were the major frameworks used in building the cross - case analysis.

\subsection{Cross - Case Analysis}

The cross-case analysis is presented to identify similarities and differences of the three cases. The supplier selection criteria, dimensions and roles in buying center and lastly the factors influencing the buying process are discussed.

\subsubsection{Buy Classes, Dimensions and Roles at Anbessa, TikurAbbay and Peacock}

\section{A) Buy Class Practice}

All three case companies apply similar group of purchase (i.e. repetitive purchase and modified purchase). As they purchase similar raw materials all the time new task purchase does not occur.

\section{B) Dimensions of the Buying Center}

With respect to the dimensions of buying center, the study presents the following analysis in the table. And the dimensions are;

$>$ Vertical Involvement,

$>$ Lateral Involvement,

$>$ Extensivity Involvement,

$>$ Connectedness Involvement, and

$>$ Centrality Involvement.

The five involvements of the company buying center are briefly explained in the following table; 
Organizational Buying Behavior of Companies in Ethiopia

Table 4.1: The three companies dimensions of buying center

\begin{tabular}{|c|c|c|c|}
\hline Dimensions & Anbessa & TikurAbbay & Peacock \\
\hline $\begin{array}{l}\text { Vertical } \\
\text { involvement in } \\
\text { straight rebuy }\end{array}$ & $\begin{array}{l}\text { Not Available } \\
\text { Upper level } \\
\text { Lower level }\end{array}$ & $\begin{array}{l}\text { Policy level } \\
\text { Upper level } \\
\text { Lower level }\end{array}$ & $\begin{array}{l}\text { Policy level } \\
\text { Upper level } \\
\text { Lower level }\end{array}$ \\
\hline $\begin{array}{l}\text { Vertical } \\
\text { involvement in } \\
\text { modified rebuy }\end{array}$ & $\begin{array}{l}\text { Policy level } \\
\text { Upper level } \\
\text { Lower level }\end{array}$ & $\begin{array}{l}\text { Policy level } \\
\text { Upper level } \\
\text { Lower level }\end{array}$ & $\begin{array}{l}\text { Policy level } \\
\text { Upper level } \\
\text { Lower level }\end{array}$ \\
\hline $\begin{array}{l}\text { Lateral } \\
\text { involvement in } \\
\text { straight rebuy }\end{array}$ & $\begin{array}{l}\text { procurement and } \\
\text { supplies production } \\
\text { quality and design } \\
\text { Not Available }\end{array}$ & $\begin{array}{l}\text { Procurement and } \\
\text { supplies Production } \\
\text { Finance } \\
\text { Not Available }\end{array}$ & $\begin{array}{l}\text { Local purchasing } \\
\text { Production } \\
\text { Planning } \\
\text { Management } \\
\text { Information System }\end{array}$ \\
\hline $\begin{array}{l}\text { Lateral } \\
\text { involvement in } \\
\text { modified rebuy }\end{array}$ & $\begin{array}{l}\text { procurement and } \\
\text { supplies production } \\
\text { design and quality }\end{array}$ & $\begin{array}{l}\text { Procurement and } \\
\text { supplies Production } \\
\text { PDC and quality } \\
\text { Finance }\end{array}$ & $\begin{array}{l}\text { Local purchasing } \\
\text { Production } \\
\text { Product } \\
\text { Development } \\
\text { System, Planning } \\
\text { Management } \\
\text { Information System }\end{array}$ \\
\hline $\begin{array}{l}\text { Extensivity in } \\
\text { straight rebuy }\end{array}$ & 6 & 7 & 6 \\
\hline $\begin{array}{l}\text { Extensivity in } \\
\text { modified rebuy }\end{array}$ & 7 & 8 & $8-9$ \\
\hline $\begin{array}{l}\text { Connectedness in } \\
\text { straight rebuy }\end{array}$ & Witten with less verbal & Witten with less verbal & $\begin{array}{l}\text { Witten with less } \\
\text { verbal }\end{array}$ \\
\hline $\begin{array}{l}\text { Connectedness in } \\
\text { modified rebuy }\end{array}$ & Witten with less verbal & Witten with less verbal & $\begin{array}{l}\text { Witten with less } \\
\text { verbal }\end{array}$ \\
\hline $\begin{array}{l}\text { Centrality in } \\
\text { straight rebuy }\end{array}$ & Purchasing director & purchasing manager & purchasing manager \\
\hline $\begin{array}{l}\text { Centrality in } \\
\text { modified rebuy }\end{array}$ & Purchasing director & purchasing manager & purchasing manager \\
\hline
\end{tabular}

Source: Own Survey, 2014

EJBE Vol. 4 No. 2/2014

Page 298 
Organizational Buying Behavior of Companies in Ethiopia

The numbers of hierarchal levels in both straight rebuy and modified rebuy are exactly the same or equal in all the three cases hence excluding the new task. The three have two similar lateral involvements in both rebuys but have totally different additional departments. However Anbessa and Tikur Abbay companies have exact similar department which is not totally named in Peacock Company. The extensivity in a straight rebuy for both Anbessa and Peacock is same and six in number but Tikur Abbay has seven individuals. Furthermore, extensivity in a modified rebuy of Tikur Abbay and Peacock are sometimes equal but in Anbessa the individual involvement is totally different. The connectedness and centrality, the three case companies have exact the same mods of communication and similar personnel.

\section{C) Roles in the Buying Center}

\section{Table 4.2: Roles of the Case Companies Buying Center}

\begin{tabular}{|l|l|l|l|}
\hline \multicolumn{1}{|c|}{ Roles } & \multicolumn{1}{|c|}{ Anbessa } & \multicolumn{1}{c|}{ TikurAbbay } & \multicolumn{1}{c|}{ Peacock } \\
\hline $\begin{array}{l}\text { Initiator in } \\
\text { straight rebuy }\end{array}$ & $\begin{array}{l}\text { Store clerk or } \\
\text { Supervisor }\end{array}$ & $\begin{array}{l}\text { Store clerk or } \\
\text { production } \\
\text { manager }\end{array}$ & $\begin{array}{l}\text { production } \\
\text { planning head }\end{array}$ \\
\hline $\begin{array}{l}\text { Initiator in } \\
\text { modified rebuy }\end{array}$ & $\begin{array}{l}\text { Designer or } \\
\text { production } \\
\text { manager }\end{array}$ & $\begin{array}{l}\text { Designer or } \\
\text { production } \\
\text { manager }\end{array}$ & Designer or \\
customer
\end{tabular}

EJBE Vol. 4 No. 2/2014

Page 299 
Organizational Buying Behavior of Companies in Ethiopia

\begin{tabular}{|l|l|l|l|}
\hline $\begin{array}{l}\text { Gatekeeper in } \\
\text { modified rebuy }\end{array}$ & $\begin{array}{l}\text { Purchasing } \\
\text { manager }\end{array}$ & $\begin{array}{l}\text { Purchasing } \\
\text { manager }\end{array}$ & $\begin{array}{l}\text { Local } \\
\text { Purchasing } \\
\text { manager }\end{array}$ \\
\hline $\begin{array}{l}\text { Purchaser in } \\
\text { straight rebuy }\end{array}$ & $\begin{array}{l}\text { Any one from } \\
\text { purchasing } \\
\text { department }\end{array}$ & $\begin{array}{l}\text { Any one from } \\
\text { purchasing } \\
\text { department }\end{array}$ & $\begin{array}{l}\text { Driver of the } \\
\text { company }\end{array}$ \\
\hline $\begin{array}{l}\text { Purchaser in } \\
\text { modified rebuy }\end{array}$ & $\begin{array}{l}\text { Any one from } \\
\text { purchasing } \\
\text { department }\end{array}$ & $\begin{array}{l}\text { Any one from } \\
\text { purchasing } \\
\text { department }\end{array}$ & $\begin{array}{l}\text { Driver of the } \\
\text { company }\end{array}$ \\
\hline $\begin{array}{l}\text { Users in } \\
\text { straight rebuy }\end{array}$ & Production units & Production units & Production units \\
\hline $\begin{array}{l}\text { Users in } \\
\text { modified rebuy }\end{array}$ & Production units & Production units & Production units \\
\hline
\end{tabular}

Source: own survey, 2014

Considering the result from the cross-case analysis of the number of hierarchal levels, departments and individuals in addition to the central player and communication network involved. And in straight rebuy as compared to the modified rebuy, the similarity of the dimensions of the buying center between the three cases is visible. This occurs due to the organizational task likeness of the three case companies. Furthermore, the buying process of the finished leather is conducted in an industry wide standardized manner. Generally, in both straight and straight rebuy, the only difference in some part at initiator, decider and purchase of the finished leather. Surprisingly, in peacock customers sometimes incite the modified purchase which is not practiced in the other two case companies.

\section{Straight rebuy}

The initiator has similar position in Anbessa and TikurAbbay but totally different position in Peacock. The deputy general manager is the one who decides in Tikur Abbay and Peacock companies rather the purchasing manager decides in Anbessa Shoe Company. Furthermore, all people who are involved in the process influence the leather purchase and the gatekeeper is the purchasing manager in all the three case companies. Any one from purchasing 
Organizational Buying Behavior of Companies in Ethiopia

department buys the leather for both Anbessa and Tikur Abbay but the driver is the one who is responsible for Peacock. Finally, the cutting, stitching, lasting and finishing units in production department uses the purchased finished leather and produce shoes for export.

\section{Modified rebuy}

The initiator has similar position in Anbessa and Tikur Abbay but half similar in Peacock with respect to the designer. The general manager decides the purchase in all three companies. All people who are involved in the process influence the leather purchase and the gatekeeper is the purchasing manager in all the three case companies. Any one from purchasing department buys the leather for both Anbessa and Tikur Abbay but the driver is the one who is responsible for Peacock. Finally, the cutting, stitching, lasting and finishing units in production department uses the purchased finished leather and produce shoes for export.

Generally, in both straight and straight rebuy, the only difference in some part at initiator, decider and purchase of the finished leather. Surprisingly, in peacock customers sometimes incite the modified purchase which is not practiced in the other two case companies 


\subsubsection{Selection Criteria}

The following table presents Anbessa's, Tikur Abbay's and Peacock's supplier selection criteria.

Table 4.3: Cross-case analysis: selection criteria of the case companies

\begin{tabular}{|c|c|c|c|}
\hline Criteria & $\begin{array}{l}\text { Anbessa's } \\
\text { Evaluation }\end{array}$ & $\begin{array}{l}\text { TikurAbbay } \\
\text { Evaluation }\end{array}$ & $\begin{array}{l}\text { Peacock's } \\
\text { Evaluation }\end{array}$ \\
\hline Quality & $\begin{array}{l}\text { Extreme } \\
\text { importance }\end{array}$ & Extreme importance & Extreme importance \\
\hline Delivery & $\begin{array}{l}\text { Extreme } \\
\text { importance }\end{array}$ & Extreme importance & Extreme importance \\
\hline $\begin{array}{l}\text { Performance } \\
\text { history }\end{array}$ & $\begin{array}{l}\text { Considerable } \\
\text { importance }\end{array}$ & Slight importance & $\begin{array}{l}\text { Considerable } \\
\text { importance }\end{array}$ \\
\hline $\begin{array}{l}\text { Warranties and } \\
\text { claim policies }\end{array}$ & $\begin{array}{l}\text { Considerable } \\
\text { importance }\end{array}$ & Slight importance & $\begin{array}{l}\text { Considerable } \\
\text { importance }\end{array}$ \\
\hline $\begin{array}{l}\text { Production } \\
\text { facilities and } \\
\text { capacity }\end{array}$ & $\begin{array}{l}\text { Considerable } \\
\text { importance }\end{array}$ & $\begin{array}{l}\text { Considerable } \\
\text { importance }\end{array}$ & $\begin{array}{l}\text { Considerable } \\
\text { importance }\end{array}$ \\
\hline Price & $\begin{array}{l}\text { Considerable } \\
\text { importance }\end{array}$ & Extreme importance & $\begin{array}{l}\text { Considerable } \\
\text { importance }\end{array}$ \\
\hline $\begin{array}{l}\text { Technical } \\
\text { capability }\end{array}$ & $\begin{array}{l}\text { Considerable } \\
\text { importance }\end{array}$ & Slight importance & $\begin{array}{l}\text { Considerable } \\
\text { importance }\end{array}$ \\
\hline Financial position & $\begin{array}{l}\text { Considerable } \\
\text { importance }\end{array}$ & $\begin{array}{l}\text { Considerable } \\
\text { importance }\end{array}$ & $\begin{array}{l}\text { Considerable } \\
\text { importance }\end{array}$ \\
\hline $\begin{array}{l}\text { Procedural } \\
\text { compliance }\end{array}$ & $\begin{array}{l}\text { Considerable } \\
\text { importance }\end{array}$ & $\begin{array}{l}\text { Considerable } \\
\text { importance }\end{array}$ & $\begin{array}{l}\text { Considerable } \\
\text { importance }\end{array}$ \\
\hline $\begin{array}{l}\text { Communication } \\
\text { system }\end{array}$ & $\begin{array}{l}\text { Considerable } \\
\text { importance }\end{array}$ & $\begin{array}{l}\text { Considerable } \\
\text { importance }\end{array}$ & $\begin{array}{l}\text { Considerable } \\
\text { importance }\end{array}$ \\
\hline
\end{tabular}

Source: Own Survey, 2014

Quality and delivery are considered as extremely important criteria by the three cases, as the criteria have been the back bone in the industry buying. Price as a criterion is extremely important in Tikur Abbay, as enormous cost pressure pushes the company. However, price as criteria is not in line with Dickson's study's supplier selection criterion which is considered as important. Butit's ranked as considerable important by the other two companies because small 
price difference can be negotiated so long as the leather quality and delivery are superior.

The rest seven criteria mentioned in the above table are prioritized and considerably important for Anbessa, Peacock and Tikur Abbay companies. Except technical capability, performance history and warranties and claim policies which are slightly important in Tikur Abbay.

\subsubsection{Factors Affecting Case Companies Buying Process}

Table 4.4: factors influencing the case companies buying process and the buying center

\begin{tabular}{|c|l|l|l|}
\hline Factor & \multicolumn{1}{|c|}{ Anbessa } & \multicolumn{1}{c|}{ TikurAbbay } & \multicolumn{1}{c|}{ Peacock } \\
\hline $\begin{array}{c}\text { Environme } \\
\text { ntal }\end{array}$ & $\begin{array}{l}\text { Economical, } \\
\text { Technological, } \\
\text { cultural, political } \\
\text { and legal Factors }\end{array}$ & $\begin{array}{l}\text { Economical, } \\
\text { Technological, } \\
\text { cultural, political } \\
\text { and legal Factors }\end{array}$ & $\begin{array}{l}\text { Economical, } \\
\text { Technological, } \\
\text { cultural, political } \\
\text { and legal Factors }\end{array}$ \\
\hline $\begin{array}{c}\text { Organizati } \\
\text { onal }\end{array}$ & $\begin{array}{l}\text { Structure and Task } \\
\text { Factors }\end{array}$ & $\begin{array}{l}\text { Structure and Task } \\
\text { Factors }\end{array}$ & $\begin{array}{l}\text { Structure, Task } \\
\text { and Goal Factors }\end{array}$ \\
\hline $\begin{array}{c}\text { Buying } \\
\text { center }\end{array}$ & $\begin{array}{l}\text { Interest and } \\
\text { Perception Factors }\end{array}$ & $\begin{array}{l}\text { Interest and } \\
\text { Perception Factors }\end{array}$ & $\begin{array}{l}\text { Interest and } \\
\text { Perception Factors }\end{array}$ \\
\hline $\begin{array}{l}\text { Individual } \\
\text { Age, Education }\end{array}$ & $\begin{array}{l}\text { Age, Education and } \\
\text { and Experience }\end{array}$ & Experience Factors & $\begin{array}{l}\text { Age, Education } \\
\text { and Experience } \\
\text { Factors }\end{array}$ \\
\hline
\end{tabular}

Source: own survey, 2014

As shown in table 4.4, the case companies have similar factors of influencing their purchasing process. For instance, the political stability and technological facilities of the country are benefiting the companies, but the import and export regulation of the country is hindering their buying and selling process. However, the knowledge of the peasants and brokers on how to handle the raw hide and skin is minimal and is affecting the overall buying situation. 
Organizational Buying Behavior of Companies in Ethiopia

Depending on the result the researcher can conclude that likenesses occurred because the companies act in one industry and they follow almost similar kind of purchasing practices. Furthermore, the professional workers who circulate in the industry bring similarity in terms of knowledge, experience and other individual factors.

\section{Conclusion and Recommendations}

\subsection{Conclusion}

There happened to be a clash with the theory about the buy classes proposed by Robinson et al. (1967). As purchases in the three case companies are divided into two groups (i.e. repetitive purchase and modified purchase) not three as proposed by the theory. As the footwear companies purchase similar raw materials all the time new task purchase does not occurr.

Besides, a case study of Swedish Heavy Truck Industry by Krig and Stenstrom (2001) revealed that the two types of purchases are exercised by excluding the new task. The result of dimensions and roles in the buying center shows that there is almost perfect match between the case companies. Furthermore, the study present that similarity of roles in the buying center in both straight and modified rebuys situations. The finding shows that the supplies selection criteria of Anbessa and Peacock companies are an exact match but have a slight difference with TikurAbbay company. Moreover, quality and delivery are extremely important of the case companies similar to the finding of heavy truck company case study by Krig and Stenstrom (2001). Finally, all the factors suggested byWebster and Wind (1972), affects the case companies buying process and buying centers. Moreover, a case studies of lubricants in Zambian industry, KITWE based companies by Chisakulo (2002) resulted in similar manner.

\subsection{Recommendations}

Some managers prioritize credit facility criteria higher than quality criteria and this can create a huge gap in the production as quality of a product is a major issue in purchasing finished leather.

EJBE Vol. 4 No. 2/2014 
It is recommended if the case company can assign one responsible person for purchasing the finished leather, it will bring a huge difference on the finished leather shoes.

The managers of the companies should give attention to the factors that influence their purchasing process especially to the negative impacts like low staff interest and perception, culture, technology, etc.

If the Ministry of Industry can monitor the purchasing process of footwear companies closely and taking prompt decision, the footwear export performance can be enhanced with effective communication and clear procedures.

Leather Industry Development Institute (LIDI) could benchmark good practices from different countries that have efficient leather supply chain, as it is doing in the production process with India, the overall finished leather activity would be in line with process and output performance. Furthermore, LIDI should give due attention to the educational package of leather quality, by teaching the peasants and sellers as they damage the raw hide and skin unknowingly.

\subsection{Limitations and Directions for Future Research}

Due to the qualitative nature, results are explained in word than in numeric evidence. Besides, the explanations are mainly depending on the researcher's analytical knowledge thus, it might have limitation on exactly transferring the respondent's idea and interest.

Sample is selected purposively and the results are the reflection of those selected respondents. Moreover, bias might occurre due to the wrongly applied selection parameters. Therefore, the study might have limited representativeness of the findings for the target population.

The description of leather footwear industry buying behavior was limited to listed theoretical variables. Though these variables were included and proven to be accurate in other studies, there could be other relevant variables that are likely to describe the organizational buying behavior more accurately. Consequently, future research should try to identify and include other relevant theoretical variables that were not considered in this study. 
Organizational Buying Behavior of Companies in Ethiopia

This study is only limited to one leather sector which is leather footwear industry. The model could be modified to see the buying behavior of different industries like leather processing, garment and goods industries. This will enable to compare and see the overall leather sector purchasing practice and provide whole lot information for the managers to make correct leather purchasing process.

$>$ Finally, Understanding and analyzing the buying behavior of end users is also very important and interesting to wholly comprehend the buying behavior aspects which this study failed to include. Thus, if future studies can include it, the result can be a whole sum of the buying behavior. 
Organizational Buying Behavior of Companies in Ethiopia

\section{References}

Anderson, E.; Chu, W.; and Weitz, B. (1987). Industrial Purchasing: and Case Exploration of the Buy Class Framework. Journal of Marketing, 57 (7), pp. 71-86.

Bonoma, T.V. (1982). Major Sales: Who Really Does the Buying? Harvard Business Review, (May-June), pp.1-12.

Bunn, M.D. (1993). Taxonomy of Buying Process Approaches.Journal of marketing, 57(1), pp. 38-56.

Central Statistic Authority, (2012/13a).Agricultural Sample Survey Livestock and Livestock Characteristics.Unpublished manuscript, Private Peasant Holdings, Federal Democratic Republic of Ethiopia, Vol 2.

---- (2012/13b).Small Scale Manufacturing Industry. Unpublished manuscript, Statistical Survey, 2012/13.

Cheraghi, S.H.; Dadashzadeh, M.; and Subramanian, M. (2004). Critical Success Factors for Supplier Selection: An Update. Journal of Applied Business Research, 20 (2), pp. 91-108.

Chisakulo, E. (2001). Organizational Buying Behavior of Lubricants in Zambian Industrial Markets: A Case of KITWE Based Companies. Master"s thesis, Copper Belt University.

Fill, C. and Mckee, S. (2011). The Theory and Practice of B2b Marketing. In: Cousins, J.; Foskett, D.; and Pennington, A. (eds.) Business Marketing Face To Face. Woodeaton: Good fellow, pp. 63-83.

Goncalves, R. and Vaquer, J.C. (2006).Organizational Buying Behavior and Word-Of-Mouth. Lulea University of Technology (http: www. Epubl.ltu.se/1653-0187/2006/26/LTU-PB-EX-0626-SE.pdf).

Hass, R.W. (1995). Business Marketing: A Managerial Approach. 6th edition. South Western College: Ohio.

Johnston, W.J. and Bonoma, T.V. (1981) The Buying Center: Structure and Interaction Patterns. Journal of Marketing Management, 45 (3), pp. 143156.

Kotler, P., Armstrong, G., and Saunders, J. (1996).Principles of Marketing. European Edition. Hemel Hempstead, Hertfordshire: Prentice Hall. 
Organizational Buying Behavior of Companies in Ethiopia

Krig, J.A. and Stenstrom H.M. (2001). Buying Behavior in the Swedish Heavy Truck Industry: an Case Study of Volvo and Scania Truck Corporation. Lulea Tekniska University of Technology (http: www. Epubl.luth.se/14045508/2001/107/LTU-SHU-EX-01107-SE.pdf).

Leather Industry Development Institute, (2012/13).Leather and leather product factories annual export performance. Unpublished Manuscript, Addis Ababa.

Leather Industry Development Institute, (2014).Leather companies profile. Unpublished Manuscript, Addis Ababa.

Mekonnen Bekele and Gezahegn Ayele, (2008).the Leather Sector: Growth Strategies Through Integrated Value Chain.Unpublished Master's Thesis, Ethiopian Development Research Institute (EDRI).

MulualemEshetu, (2002).The Performance and Determinants of The Ethiopian Leather Export Sector.Unpublished Master's Dissertation, Addis Ababa University.

Robinson, P.J.; Fairs, C.W.; and Wind, Y. (1967).Industrial Buying in Creative Marketing. Boston: Allyn and Bacon Inc.

Saunders, M., Lewis, P., and Thornhill, A. (2009).Research Methods for Business Students.5th edition. Pearson Educational Limited: Prentice Hall.

Tomas Cherkos, (2011).Performance Analysis and Improvement of Ethiopian Leather Footwear Factories: With Special Reference to Anbessa Shoe S.C. Unpublished Master's dissertation, Addis Ababa University.

Webster Jr, F.E. and Wind, Y. (1972).A General Model for Understanding

Organizational Buying Behavior. Journal of Marketing, 36 (2), pp. 12-19.

Yin, R.K. (2003).Case Study Research: Design and Methods. Third Edition. Thousand Oaks, CA: Age Publication. 